\title{
Podstrochnichestvo in Prose Pants: A Rising Mode of Verse Translation
}

RUSSIAN POETRY UNDER THE TSARS: AN ANTHOLOGY. Translated, and with an introduction and notes, by Burton Raffel. Albany: State University of New York Press, 1971. xxvii, 245 pp. $\$ 10.00$.

The practice of team translation of poetry, by which a poet wholly or partly unfamiliar with the base language is tutored in various ways by one or several native experts, is increasingly coming into favor. Where it is combined with a disregard for the semantic and metric identity of the original-for the sake of would-be "modernization" and/or to obviate the formidable difficulties involved -it seems quite important to examine the product carefully and, if necessary, interpose a caveat lector. Mr. Burton Raffel's last-but-one volume of this character furnishes a not untypical sample on which to attempt this kind of consumer test.

This handsome book, exemplarily and expansively printed in a square album format allowing for more white space than text, offers selections from thirty-four poets, starting with two samples of oral poetry and ending with four poems by Marina Tsvetaeva. The average number of selections (except for Pushkin) is about three for each poet; only Lermontov, Tiutchev, Fet, and Blok are represented by two or three more. Pushkin figures with thirteen of his shorter poems ; but the addition of Mozart and Salieri, The Golden Cockerel, and The Bronze Horsemain swells the Pushkin section to about one-quarter of the book. Incidentally, all these-the rhymed fairy tale, the rhymed dramatic poem, and the blank-verse "little drama"-are uniformly reduced to prose lines of unequal length with occasional rhymes and assonances. Each poet is introduced by a quarter-page to page-and-a-half sketch, a curriculillum vitae et operum with a portrait where available; Pushkin is given four and a half pages. Most of these sketches are informative and balanced despite their brevity, and written with a pleasant light touch; some are strangely laconic or one-sided.

The selections as a whole are given a twelve-page send-off by $\mathrm{Mr}$. Raffel, offering impressions and deductions from his reading in and about Russian literature-especially, of course, poetry-over the great span traced by his title. With no pretensions to originality or critical balance, but often perceptive in detail and judicious in choice and phrasing of generalizations, he comments on some general trends in the development and Westernization of Russian poetry, 
pauses with the alleged ravages of Polish word stress and other metric matters (leaning largely on Nabokov's Notes on Prosody), remarks on eighteenthcentury poets and the century's achievements in poetry, touches on the tension between literature and autocracy in the nineteenth century, and tries his hand, very briefly indeed, at the aims and hallmarks of the literary movements between 1880 and the Revolution. Finally he adds a few words on his principles of selection and translation.

On the first subject he says, "The editorial selection has been aimed at a representative sampling. ... I have tried, also, to give fuller coverage to the more important figures-Pushkin especially, but also Lermontov, Tyutchev, Fet, Blok, Akhmatova. I think the book in fact offers a representative if somewhat eccentric group of translations, showing the growth and development, and hopefully also the excellences, of Russian poetry up to the Revolution" (p. xxv).

On the second question-what sort of translation is here offered the reader and why-he finds it, perhaps understandably, even more difficult to be informative and specific: "This book is the product of one particular American poet and translator interacting with a group of Russian poets. Some of the translations will reflect, more accurately than others, the essential spirit of their originals. ..." He then quotes: "'to translate a poem whole is to compose another poem. A whole translation will be faithful to the matter, and it will "approximate the form," of the original ; and it will have a life of its own, which is the voice of the translator. ... He must make another poem that will speak, or sing, with his own voice' (Jackson Matthews, "Third Thoughts on Translating Poetry," in On Translation, p. 67)" (p. xxvi). Some of his versions, he notes, are superior to others, which render poets in whom he is less interested: "I am an experienced translator-but also a unitary being. There are advantages to a book and to an approach of this sort, but plainly one of them is not, nor can it be, equivalent reflections of each and all the different poets translated. The technical aspects of these translations are hard for me to discuss. This is not, I want to stress, an evasion, but a simple fact. . . . In general, the twentiethcentury poets were harder for me to rhyme, in translation. But I do not know why, though $I$ have some rather vague guesses. Clear answers, if any exist, lie too deep for me to dredge them out: basically, I have done what I have done because it seemed best to me, poem by poem; seemed to work best in English as a representation of what I saw as the poetic quality of the Russian. Translating poetry may be as subjective an art as writing poetry-it is, for me at any rate-but the reader is entitled to know, also, that these are translations, not imitations. ... I have not in any case tried to compose an original poem, using a Russian poem as a model, as an inspiration, or as a kind of quarry" (pp. xxvixxvii). 
For an explanation of the external raison d'être of this volume, besides Mr. Raffel's private interaction with Russian poets, we may consult the dust jacket, which states: "Russian Poetry under the Tsars is both an act of homage, by a translator whose parents were born in Russia, and a determined attempt to bridge a cultural gap formidable in size and of very long standing. There is not a single Russian poet, classic or contemporary, who has entered the mainstream of English and American literature... The basic difficulty is that, apart from some recent attempts to involve poets in the translation of Russian verse, it has come to us, in English, through the devoted, dogged, dull work of scholars, linguists, rhymsters [sic], poetasters, and indeed almost anyone who has come to know Russian or who has spent a few years in residence in Russia. Russian Poetry under the Tsars is a poet's book, a poet's attempt to show English-speaking readers some of the glories of pre-Revolutionary Russian verse." This begs a polite question, of course. If the worms at the root of that dream lily, Russian poetry Englished in its glory, were those devoted, dogged dullards who know Russian but are various deplorable sorts of -ists, -esters, and -asters in English (often true), what about those who, with one hand stretched out to a Russian expert beyond, try to reach across from the other side of the interlingual gulf-the English poets? (each committed to a meritorious personal "idiom" and equipped with an attested variant of "modern sensibility," but having no Russian, or too little to work with confidence directly from the originals). Are they-the Lowells, Audens, Smiths, Blys, Kunitzes-perhaps a parliament of worms of a different constituency, gnawing at the other side of that sorely tried lily bulb? We cannot take space to sample them here, and certainly must guard against throwing them all into the same bag. But the bilingual samplers of these teamwork products have found that few, if any, manifest a true blood relationship with their originals.

It is abundantly clear that Mr. Raffel does not belong to the first species of bulb-eaters. Not only do his publishers implicitly disclaim it, not only is he a poet of repute rather than a dogged dullard, but if he did belong to that species his versions would have been more disciplined and disparate in diction and meter from poet to poet, and the originals would have remained more recognizable and distinguishable. Whether he belongs essentially to the second gender, the reader cannot possibly tell ; the dust jacket is clearer than the introduction is about the working basis and rationale of his translation process only in that it says nothing about it. Yet one would greatly like to know, for there is obviously a high order of intelligence and enthusiasm at work here, as well as a gratuitous and exasperating svoenravie in letting form, detail, and flavor go hang, not only under occasional duress, but with a high hand, $a b$ initio, and, as it were, faute de pis. A clue, but possibly a misleading one, may lie in the fact that over long stretches far more than half his selections are identical with 
those of the Penguin anthology edited by Obolensky, which is equipped with prose translations-a book which Mr. Raffel mentions has "frequently guided him" and been useful to him "in a variety of ways" (p. xxv). Were the prose translations among these ways? Does Mr. Raffel work from linear translations, and perhaps with further expert guidance in the delicate, all-important matter of lexical connotations, syntactical and modal flavors, prosodic and tonal values? We understand from the podstrochniki of the remote-control poet-translators that though the latter sometimes barely touch up the translations elaborated for and with them by the podstrochnik, quite often they up and take great leaps and veers outward and away from the original and, communing directly with their brother spirits across the ages, throw off the checkrein almost at once, with startling results.

The remote-control method, of course, has become increasingly fashionable lately, owing to the concurrence of idle but ill-judged sighs from reviewers ("It would take an English poet of rank to ...") with the serial resurrection by scholars and memoirists of great untranslated Russian poets like Blok, Tsvetaeva, Gumilev, Akhmatova, Esenin, Mandelshtam (for Wasps and Germans: Mandelstam), who are whetting more and more vagrant appetites. Intuitively one would tend to decide, perhaps, that $\mathrm{Mr}$. Raffel does not attend anyone's manège, or has not lately, at least. If he does, one may wonder who the power behind the throne is. There is Sidney Monas, who worked on the Umdichtung of the Slovo with him (Delos, no. 6), and who is to function as the general editor of the prospective series, "Russian Literature in Translation"; and there is Miss Alla Burago, who figures as Mr. Raffel's cotranslator in the first volume planned for this series, Selected Works of Nikolai S. Gumilev, as well as for "The Complete Poetry of Osip Mandelstam" and a book of Pushkin translations. Yet a substantial foster-relationship of this sort on the present volume would presumably have been acknowledged somewhere in title or preface; furthermore, Mr. Raffel is no novice of the craft, but the author of a treatise on translation (The Forked Tongue: A Study of the Translation Process); yet again, consulting this work might not have helped to establish the above point about Russian, for he earlier translated from Old English and Vietnamese, possibly one other language, and edited an anthology of Indonesian poetry.

This reviewer is at fault in not having consulted the poet himself beforehand; but the point does not perhaps matter greatly, for it seems clear on the evidence of this volume, and all but a handful of translations published by English poets from Russian, that a poet nurturing ambitions, and in the settled habit, of writing a poem in his own idiom (even if based in some sense on a foreign poem) will not or cannot create a metrically, cognitively, and atmos- 
pherically faithful translation of any poem not adventitiously congenial to him in these respects, whether or not he is linguistically privy to the spontaneous sensual "feel" of the original. He may quite often produce an artifact of fresh interest and merit-in fact, the very thing Mr. Raffel disclaims doing, an imitation. As an anthologist, however, he is under an obvious and formidable handicap (an anthology like Mr. Raffel's would require, one suspects, half-adozen different hands, carefully selected). Each Russian poet selected here emerges sounding very much like every other, with the personal signatures of rhyme, meter, diction, and much of the content, ground away. And since, in addition, the Russian titles are nowhere in evidence and untitled poems are supplied with new English titles, one finds it unexpectedly hard to match the translations with their originals and feels quite grateful for the solid binding; if ever the pages came apart, reassembly by anyone but the translator would be a challenging philological task.

These generalities over, it may be instructive to inspect some specific samples and juxtapose, for example, Pasternak's poem "Hamlet" with, first, Lydia Pasternak Slater's English version (which, not without lapses, approximates the original trochaic pentameter and rhymes, more or less, two lines per quatrain) and, next, Mr. Raffel's spirited rendering with its characteristic freebeat, stretch-sock, universal-fit line and his casual scrabble for a half-rhyme here and there:

\section{ГАМЛЕТ}

Гул затих. Я вытелг на подмостки, Прислонясь в дверному кослку, Я довлю в далеком отгодоске, Что случится на моем веку.

На мевя наставлен сумрак ночи Тысячьюо биноклей на оси.

Если тольво можно, Авва 0тче, Чапу өту мимо пронеси.

Я люблю Твон замысел упрямын

И итрать согласен өту роль.

Но сейчас идет другая драмг, И на этот раз меня уволь.

Но продумав распорядок деисствй, И неотвратим вонец пути. Я один, все тонет в фарисействе. Жиизнь пролить - не поле перейти. 


\section{HAMLET}

Translated by Lydia Pasternak Slater1

The murmurs ebb; onto the stage I enter, I am trying, standing in the door, To discover in the distant echoes What the coming years may hold in store.

The nocturnal darkness with a thousand Binoculars is focused onto me.

Take away this cup, O Abba, Father, Everything is possible to thee.

I am fond of this thy stubborn project, And to play my part I am content. But another drama is in progress, And, this once, $O$ let me be exempt.

But the plan of action is determined, And the end is irrevocably sealed. I am alone; all round me drowns in falsehood:

Life is not a walk across a field.

\section{HAMLET}

\section{Translated by Burton Raffel}

They're quiet. I mount the stage.

Leaning on an open door I strain at an echo, far off, hunting what the future is for.

The rim of night shines back at me from a thousand peering glasses. If You can, Abba, Father, let this cup be passed

Away from me. I adore Your stubborn plan, I will smile and read the lines.

But tonight it's a different script so excuse me, please, this time.

Yet scene must follow scene, the road goes where it goes. I'm alone, everything drowns in a pious show.

Life is no casual jingle.

1. Reprinted from 50 Poems by Pasternak by permission of Lydia Pasternak Slater and the publishers, George Allen \& Unwin Ltd. 
One can see where, in the first translation, greater fidelity and rhythmic ease is bought at the minor cost of some lexical diffuseness and a few mildly awkward inversions, while in the second, at greater cost, the reverse bargain is struck. Neither seems a strikingly good solution; but Mrs. Slater's conveys far more about Pasternak and his poem, and, bless her, gets the wry and folksy last line right. Mr. Raffel's, to many contemporary readers, may be "denser" and more interesting ; but this is the virtue, again, not of a translation, but of an imitation, where the new poet blots out the old instead of merging with him in a new medium. Mr. Raffel seems, to the reviewer's mind, more in his element with this relatively relaxed fin-de-siècle prosody (permitting at least a few mere half-rhymes, though still maintaining great metric rigor) than with nineteenthcentury poets. Yet one wonders; with so much freedom usurped, why so much needless inaccuracy? When there is little or no constraint of rhyme or meter, why, for example, gratuitously strip the last line of both its literal and its proverbial content?

What happens to Pushkin, who occupies one-fourth of the anthology proper? Mr. Raffel chooses his lovely, quizzically rueful, perfectly balanced untitled poem of 1830, "Kogda v ob"iatiia moi . . .," whose vital formal element is a long syntactic breath (twenty lines for three sentences), released gradually toward the end. Mr. Raffel calls it "Love Song." When it emerges from the treatment, its rich verbal substance is shrunk by about one-third, the denuded lines being sometimes left with a single chance word (e.g., "gardens"); gone is the music of rhyme and rhythm, and with it even the charming, and indispensable, main point: that the poet's own past betrayals, not some vague caveats and traditional homilies, have come to his beloved's ear and now become his nemesis by making her keep her distance. No wonder the legkovernye girls of his past (penultimate line) turn up in Raffel as "swooning," and their pozdnii ropot as "sighs." It also looks suspiciously as though Mr. Raffel had the little scene happen in bed or on a porch swing ("you rise ..."), perhaps because of rather far-reaching modern horizontal connotations of "embraces"; yet this would somewhat contradict the frustration complained of and is not in the text. Another example, not an extreme one, of this (honi soit qui mal $y$ pense) prosodic bone-crushing and meat-grinding effect may be adduced randomly from Pushkin's fragment "Autumn," one of his few uses of the intricate vehicle of the gender-alternating octave that so fascinated him in Domik $v$ Kolomne. Let us this time compare a lineal translation, a metric one, and Mr. Raffel's version, of octave 5:

\section{Lineal:}

The days of late autumn are usually scolded,

But she is dear to me, dear reader,

With (her) quiet, meekly gleaming beauty. 
Thus a child unloved in its native family

Draws me to it. To tell you frankly,

Of the times of year I am glad of her alone;

There is much good in her; an unpretentious lover,

I found something in her by my wayward fancy.

\section{Metric:}

The fading autumn almost none admires,

Yet, reader, I am fond of her, I own,

Fond of her muted glow of half-banked fires.

Like a poor child unloved among her own

She calls to me. If anyone inquires,

Her of all seasons I hold dear alone.

There is much good in her. A frugal wooer,

My whim finds some appeal quite special to her.

\section{Raffled:}

No one knows autumn;

I love it for its gentle glow

and quiet face, caught in

beauty like an unloved child lonely

and unknown. Only Fall

for me: half perfect is enough,

a quarter perfect; all

I want is this elegant roughness.

Again: cut to the bone, the metric identity thrown to the wind, the leisurely lilt shattered, yet touched up with some attractive (if alien) verbal freshness here and there. But are a few half-rhymes (never used by Pushkin) worth the price of inserting things like "caught in beauty" (autumn) and "elegant roughness" (enough), where the first is meaningless and the second poles apart from the simile's homely meaning and spirit? Pushkin was perfectly capable of talking of "elegant roughness" had it suited him; and as for the quasi-rhymes, they are not merely dubious but also useless, since rhymes for their musical effect depend on their emplacement in a fairly consistent, predictable meter. The lines "for me: half perfect is enough" and "I want is this elegant roughness" would not rhyme even if their ends rhymed. The total loss of the metric form cannot be redeemed by an occasional forlorn hodge calling hopefully to a podge perched somewhere in the thicket of random lines. What if they do find each other?

The technique and outcome are similar in The Golden Cockerel, in The Bronze Horseman, of which a random section appears below, and everywhere:

I love the air hung still

and your winter frost, 


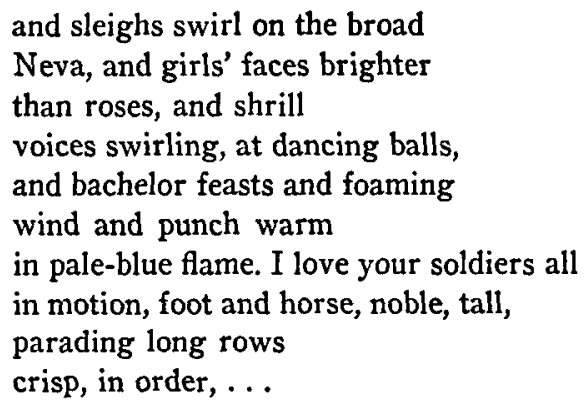

Here, surely, are the disiecta membra left after a trunk murder. This method must permit one to assemble not just izbrannye but sobrannye dela with intoxicating celerity-whole oeuvres of poetry, which took their plodding originators a lifetime to compose, cheerfully dismembered and boiled down. Kuda luchshe -how many more volumes of Pushkin might we not have if this sort of prose soliloquizing with a line-chopper and a rhyme-dropper were all it took Pushkin to create his poetry! There is a certain déjà entendu quality of Pushkin in this, but as of a medium's séance, or of someone of an excited sensibility and a memory for detail groping in impatient phrases for the elusive substance of a harmonious dream. If we want a lexically and rhythmically sensitive translation of The Bronze Horseman in a prose approximating the simple nobility of blank verse, we have Edmund Wilson's. The next higher stage is a really inspired verse translation in the true form of the original-which we do not have yet. To this reviewer's mind-and admittedly his poetic taste may be very captious and deviant-there could hardly be anything worth while in between.

Two last exhibits from the first half of the nineteenth century, where close to half the volume of the anthology belongs, are given below: first, Tiutchev's early untitled poem in three metrically varying quatrains, which Mr. Raffel calls "Dreams."

Как океан объемлет шар земной, Земная жизнь кругом обълта снами; Настанет ночь - и звучными волнами

Стихия бьет о берег свой.

То глас ее: он нудит нас и просит...

Уж в пристани волшебнын ожил челн;

Прилив растет и бнстро нас уносит

В невзмеримость темных волн.

Небесный свод, горящий славой звездной, Таинственно глядит из глубины, И мы плывем, пылающею бездной

Со всех сторон огружены. 
Metric:

Just as the ocean girds the earth around,

Life on earth's shore is ringed with dreams that bound it;

And come the night, their tuneful surf will pound it

With waves of elemental sound.

This is their voice: it clamors and exhorts us . .

Against its moorings stirs the magic bark,

The tide swells high, and swiftly it transports us

Into the endless heaving dark.

The vault of heaven, with starry glories sparkling,

Sends from the deep a twice-mysterious gaze,

And there we float, swathed on all sides in darkling

Infinities of spangled haze.

\section{Raffled:}

As the ocean circles the shore our life is surrounded by dreams.

Nights-and their heavy waves

ring like great bells against our earth.

Like a voice, forcing, inviting. . . . .

An enchanted canoe is tied at the dock, the tide swells, we whirl away

in an endless dark sea.

And the gleaming high sky

watches, somewhere, silent-

and on we sail, on every side

a flaming abyss.

And following are the original and two English versions of Lermontov's "Dream":

$\mathrm{COH}$

В полдневный жар в долине Дагестана

C свинцом в груди лежал недвижим я;

Глубокая еще дымилась рана,

По капле кровь точилася моя.

Лежал один я на песке долины;

Уступы скал теснилисл кругом,

И солнце жгло их желтые вершины

И жгло меня - но спал я мертвым сном.

И снился мне сияющий огнями

Вечерний пир в родимой стороне.

Меж юных жен, увенчанных цветами.

Пел разговор веселый обо мне. 
Но, в разговор веселый не вступая, Сидела там задумчиво одна, И в грустный сон душа ее младая Бог знает чем была погружена;

И снилась ей долина Дагестана; Знакомый труп лежал в долине той; В его груди, дымясь, чернела рана, И кровь лилась хладегщей струен.

\section{Metric:}

In a Caucasian gorge, in noon-blaze dreaming, Inert, a bullet in my breast, I lay;

And from the deeply gaping wound, still steaming, Drop after drop, my lifeblood drained away.

Alone I lay upon the sandy clearing,

And craggy ledges clustered close and steep, The sun stood high, the tawny summits searing, And searing me-but I was dead asleep.

And in a dream I saw an evening rally, Lights blazing, in the land from where I came, And heard young girls in garlands gaily dally In conversation, mentioning my name.

But through the carefree chatter one, refusing To join in it, sat pensive and apart, In some forlorn and melancholy musing, The Lord knows what, engrossed her girlish heart.

Of a Caucasian valley she was dreaming, In that far vale a man she knew lay dead, And from a black and gaping heart-wound, steaming, The lifeblood trickled in a chilling thread.

\section{Raffel:}

Burning noon, a valley in Daghestan, on my back, a bullet in my heart; still; the bloody hole steaming, my blood oozing drop by drop.

Alone on the sand, rocks and cliffs above me, burning yellow in the sun, the sun burning me, but I asleep as if dead.

And dreaming of a ball, torches and candles, in Russia, and girls hung with flowers laughing, talking about me. 


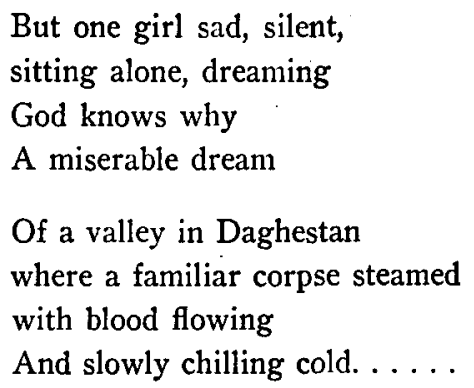

One must be permitted to wonder, in the last version, what is on whose back, who or what is still, alone, or burning, and to feel bereft by the withering away of copulas and predicates in favor of stark gerunds-an early Hemingway device to connote panting immediacy and manliness, neither of which is appropriate to the deathly sleep of the poem. The effect is-treacherous thoughtjust a little like Tom Lehrer's version of "Clementine" in the style of "Night and Day." But Raffel is an honorable poet. ... .

Mr. Raffel in this book does his own thing, and does it, often enough, with a fine verve and sparkle, but at a stellar distance from the originals. His misfortune, or rather ours, in this instance is that the overwhelming mass of the poetry he surveys lives in considerable metric rigor. Whether or not he has consulted anybody, one must doubt that even mentors of subtlety and expertise, of the caliber of Max Hayward, Sidney Monas, or Vera Dunham, can effectively hold to a strict course a poet to whom the form and diction of the original are not inseparable elements in the main glory of the poetic experience. He willperhaps must - follow his own laws, once the best and most perceptive that can be said and recited in explication and exhortation has been conveyed. He may strain the form and still save much of the original. When he dismantles it or evades it, he ceases to translate. He may still be doing something worth while in a semiprivate way, for himself and some others-as Mr. Raffel did here; especially, one feels, in the ranges of twentieth-century poetry. But for the rest-once the delicate web of the stanza or less repetitive metric unit, the pervading and containing nerve system of the whole portion of discourse, is slashed, the raw pieces of lexical content tumble out of their delicate suspension. Hereby alone, they at once revert to a prepoetic limbo, lose their identity ; for this lay as much in their particular embedding in the formal context, the way they responded or contrasted in position, grammatical structure, rhythm (not to mention sound, which is usually irretrievable anyway) to surrounding items, as it did in their own semantic identity-their denotative and connotative values, their lexical flavor. The new broom of a "contemporary idiom" brushes the pieces about, bruising some, losing more, picking up extraneous debris, and sweeps up a rude epicataclysmic lean-to in the empty place, like those Sicilian goatsheds with bits of Doric metopes in their walls. 
In view of the "idiomatic" homogeneity of the outcome, it seems idle to ponder over the particular selection of poets and poems subjected to this denaturing naturalization process. A rather uniform alienation and standardization is wrought wherever the knife strikes at the weft. Each openwork patch of terse, breathless English phrasing is sufficiently like any other in its spare texture, and sufficiently leached of the original poet's quiddity (to use a silly word for qualitas, kachestvo) to leave one in no mood to wonder if the selection of targets was in some sense "representative," and if so, what lay behind it-if indeed there was any reason besides the subjectively excellent one of the poet's private excitement by, and inner response to, the original. 